\title{
Effect of trash content on the measurements of fiber quality in Egyptian cotton.
}

\author{
H. S.A AHMED \\ Cotton Research Institute, Agricultural Research Center, Giza, Egypt. \\ Corresponding author: dr.hamedsayed@yahoo.com
}

\begin{abstract}
This work was carried out in the Laboratories of Technology, Division, Cotton Research Institute, and Agricultural Research Center Giza, to investigate the effect of trash content on fiber quality. Six of the commercial varieties of Egyptian cotton, were taken in the study, three extra-long staple categories, (Giza 45, Giza70 and Giza 88), delta longstaple categories, (Giza 86), and two Upper Egypt long- staple categories,(Giza 80and Giza 90), grown in 2012-2013 season. All tests were done under controlled atmospheric conditions of $65 \pm 2 \%$ relative humidity and $70 \pm 2^{\circ} \mathrm{F}$ temperature at the study the effect of the trash content on: spain length at 2.5\%, (ML 2.5\%) $\mathrm{mm}$, uniformity ratio (Ur\%), fiber strength in gram/tex. St. (g/tex) fiber elongation\% (Elon. \%), micronaire reading (Mic.) reflectance degree $(\mathrm{Rd} \%)$ and yellowness $(+\mathrm{b})$. The following fiber properties were measured using high volume Instrument (HVI). High volume fiber test system according to American Standard Testing and Materials (ASTM), (1998) and Digital fibrograph: according to ASTM (1977), prior to testing the lint cotton sample was stored and tested in a controlled atmosphere of $(65 \pm 2 \%)$ relative humidity and $21 \pm 2^{\circ} \mathrm{C}$. All the characters were significant, and correlated negatively to the increment of trash content accepted the reflectance degree (Rd \%), spain length at 2.5\%, (ML 2.5\%), fiber strength in gram/tex. St. (g/tex), micronaire reading (Mic.) characters which, correlated positively with trash content at the yellowness degree (+b). The trash content accepted were increasing, at $1 \%$ the lowermost values decreasing on: ML 2.5\%, Ur\%, St. g/tex, Elon.\%, Mic and Rd\%. But yellowness (+b) increasing. The diffraction increasing or decreasing, in the varieties. The maximum values decreasing and the first arrangement (realigning) is by fiber elongation\% they micronaire reading they strength they the reflectance degree $(\mathrm{Rd} \%)$ they spain length at $2.5 \%$ and uniformity ratio. The trash content effected were arrangement (realigning) diffraction in the all varieties at the values characteristics.
\end{abstract}

Key words: Egyptian cotton varieties, fiber, trash percentage, trash content, spain length, fiber Strength, micronaire reading, fiber quality.

\section{Introduction}

Cotton trash is known by its effect on textile processing efficiency. Removal of cotton trash is a means to improve textile spinning. trash particles originate from the cotton plant including different parts of the leaf, stem bark, seed and hull or from the local environmental including grass, sand, dust and other contamination. Cotton contamination including large trash and small pepper trash is commonly referred to as visible foreign matter. Cotton contains trash with conflicting issues such as vs. Foulk $\boldsymbol{e t}$ al, (2006) also, the quality of cotton fibers is dependent on many factors, including genetics, environmental conditions during production, and handling during harvest and processing. Dunn et al, (2002) mentioned that the investigation effect of nine lint cleaner and fiber quality relationships. Results showed that lint cleaners significant effect on lint content, fiber strength, micronair reading, fibergraph length, uniformity ratio, colorimeter reflectance and colorimeter plusb, also, lint cleaner efficiency led to that the market clearly assigns a value to each quality characteristics embodies in cotton, there by directly affecting the price that producers receive in the market.
Siddaiah et al, (2004) found that there is positively significant correlated between removal of cotton small trash and fiber physical properties. Mc Alister and Rogers (2005) investigated the effect of harvesting method on fiber and yarn quality. They reported increased micro naire, strength, upper half mean length, length uniformity and decreased Armijo et al, (2009) studied the effect of seed cotton cleaning treatments on fiber properties and trash content, found that seed cotton cleaning treatments with three cleaners or six cleaners significant effect on fiber $2.5 \%$ span length, micronair reading, short fiber content, immature fiber content, fineness, uniformity, strength, elongation, reflectance $(\mathrm{Rd})$, yellowness (+b) and count, size neps compared with the control (No cleaning). Richman and Fashini (1993), indicated that Studied the effect of bur extract or on trash in seed cotton and fiber quality, indicated that, reduce trash content in seed cotton can be improved quality attributes. Anthony (1994) found that removed the trash improved lint grade and most fiber quality Baker et al, (1992), reported that there relationship between cleaning process efficient and fiber quality. Misra et al, (1999) studied the effect of two lint cleaning on maximize producer net returns. Results clearly 
indicate that producers could save about 4 \$ /bale using only one stage of lint cleaning. These is because producers benefit more from lower lint loss in the gin plant than a smaller increase in price from one to two lint cleaning, also, this study indicated that one lint cleaning in the gin plant maximizes producer net returns. Xu and Fang (1999) indicated that values of trash content should be within the range from to $1.6 \%$ trash content is highly correlated with lint grades of the samples and fiber properties. Marey et al, (2012) showed that cleaning treatments decrease 2.5 and $50 \%$ span length and increase the color reflectance, yellowness and seed cotton grade.

\section{Materials and Methods}

The current study was carried out in Technology, Division, Cotton Research Institute, labs, during 20122013 seasons, to investigate the consequence of trash content on fiber quality of nine of the commercial varieties of Egyptian cotton, were taken in the study, three extra-long staple categories, (Giza 45, Giza 70 and Giza 88), three delta long- staple categories, (Giza 85, Giza 86 and Giza 89), and three Upper Egypt longstaple categories,(Giza 80, Giza 83, and Giza 90) varieties.

\section{Sample Preparation:}

From the raw cotton of each lint, three replicates were drowning. The lint of each replicate was mixed carefully by hand blending into representative sample which was used in determining, foreign matter content and fiber properties. Prior to testing the lint cotton sample was stored and tested in a controlled atmosphere of $(65 \pm 2 \%)$ relative humidity and $\left(70 \pm 2^{\circ} \mathrm{F}\right) 21 \pm 2^{\circ} \mathrm{C}$ at the labs of Cotton Research Institute, Agricultural Research Center, iza, Egypt.

\section{Characters Studied:}

The effect of the trash content on, spain length at $2.5 \%$, (ML 2.5\%) mm, uniformity ratio (Ur\%), fiber strength in gram/tex. St. (g/tex) fiber elongation\% (Elon.\%), micronaire reading (Mic.) reflectance degree $(\mathrm{Rd} \%)$ and yellowness $(+\mathrm{b})$.

\section{1- $\quad$ The trash content (Y)}

The trash content (Y) (trash, micro-dust and fiber fragments) was used to determine the foreign matter content in the lint samples obtained from ginning. The micro-dust and trash monitor method is based on aeromechanics separation processes where in the separations are made according to rigid scientific definitions and thoroughly proven machine design principles. The (M.T.M) separates a nominally 20 gram sample of fiber. The standard (MTM) method consists of two 1.5 minute passes of the fiber. The material which passes through the (M.T.M) is subjected to faces similar to those encountered in normal textile processing. The tests were done according to Uster Instruction Manual.

\section{1-Fiber properties:}

\section{2-1- Color of Raw Cotton:}

HVI 900A was used to determine the color measurements of raw cotton. The 900A uses an automatic pneumatic powered pressure plate to compress the sample against the inspection window with a constant amount of pressure, ensuring consistent sample presentation and simplifying the testing procedure.

(a) Reflectance ( $\mathrm{Rd} \%)$. (b) Yellowness (+b) was measured according to ASTM-D2253-66, (1998).

\section{2-2- Fiber Length:}

Fibro-graph 730 which is a computerized type was used to determine fiber length parameters, it provides automatically brushing each sample, vacuuming the sample beard straight, moving the sample into an optical sensor, and taking readings of the optical density of the sample.

(a)Span lengths at 2.5\% (ML 2.5\%). (b) Uniformity Ratio (Ur \%). were determined directly by apparatus. The tests were carried out according to the Uster Instruction Manual.

\section{2-3- Micronaire reading:}

Micronaire reading (Mic.) that is a measurement for the combination of fiber fineness and maturity was measured by Uster Micronaire 675.In this method the fiber sample is weighted on an electronic balance. This mass is accepted if its weight is between 9.5 and 10.5 grams from the measured values of mass and pressure, the microprocessor calculates specific surface from which the fineness and maturity value were derived. The tests were done according to Uster Instruction Manual.

\section{2-4- Fiber mechanical characters:}

Presley was used to determine the fiber strength at 0 inch gauge length according to standard procedure designated by the ASTM, Designation D-1445-(1967). (a)Fiber strength in gram / Tex (St. (g/tex). (b) Fiber Elongation \% (Elon.): the percentage of Elongation, which occurs before a fiber bundle breaks.

\section{3- Statistical analysis:}

Completely randomized design with nine of the commercial varieties of Egyptian cotton and three replicates was used to carry out the analysis of variance in trash content, fiber properties due to cotton varieties, The data obtained were subject to statistical analysis according to the procedure outline by Sendccor and Cochran (1989), the significant difference was used for 
comparing the different means. Simple correlation was used to study the relationship of foreign matter content.

\section{3-1- calculation:-}

Trash content $(\mathbf{Y})=$ (trash, micro-dust and fiber fragments) was used to determine the foreign matter content in the lint samples obtained from ginning, at (MTM) reading.

Value $=($ Max $-\min )$

Trash1\% = Max-mine at (Y) / (Max-mine) at characters.

Response degree $=(\operatorname{Max}-$ mine $)$ at characters $/$ (height value) at characters.

Realigning (Arrangement) $=$ the highest values decreasing and the first realigning.

Simple correlation was used to study the relationship of Actual trash content and fiber properties for some Egyptian cotton varieties.

\section{Results and Discussion}

Data in Table (1) indicated that, increasing in trash content of Giza 80 variety by $1 \%$ led to decrease, Fiber length at Fiber length at Spain length (SL 2.5\%), 1.12 $\mathrm{mm}$, Uniformity Ratio (Ur\%), $2.66 \%$, fiber strength in gram/tex 3.3 (g/tex), elongation $\% 0.78$, micronaire reading 0.53 and reflectance degree $(\mathrm{Rd} \%) 6.13 \%$. On the other hand, the yellowness degree $(+b)$ increased by $0.17 \%$. All characters are responded negatively to the increment of trash content except that of the yellowness degree $(+b)$ characters which, was increase that of by increasing the trash percentage. The highest values decreasing and the first arrangement is by micronaire reading by $41 \%$, elongation by $40 \%$, reflectance by $34 \%$, strength (g/tex) by $31 \%$, spain length (SL 2.5\%) by $13 \%$, Uniformity Ratio (UR\%), by $11 \%$. In contrast, the yellowness degree $(+b)$ increased by $5 \%$.

Table 1. Effect of trash content and response degree on fiber quality of Egyptian cotton Giza $\mathbf{8 0}$ variety.

\begin{tabular}{|c|c|c|c|c|c|c|c|c|}
\hline \multirow{2}{*}{ variety } & \multirow{2}{*}{$\begin{array}{c}\text { trash } \\
\text { content }\end{array}$} & \multicolumn{2}{|c|}{ ML } & \multirow{2}{*}{ St. g/tex } & \multirow{2}{*}{ Elon. } & \multirow{2}{*}{ Mic } & \multirow{2}{*}{ Rd\% } & \multirow{2}{*}{ b+ } \\
\hline & & $2.50 \%$ & Ur\% & & & & & \\
\hline \multirow{9}{*}{ G 80} & 1.21 & 32.62 & 88.22 & 39.73 & 7.2 & 4.75 & 65.48 & 12.85 \\
\hline & 1.67 & 31.82 & 86.9 & 39.12 & 7.05 & 4.45 & 64.22 & 12.75 \\
\hline & 2.22 & 31.35 & 85.95 & 38.58 & 7 & 4.33 & 61.93 & 12.72 \\
\hline & 3.04 & 30.31 & 83.48 & 34.1 & 6.97 & 3.36 & 57.82 & 12.67 \\
\hline & 3.32 & 29.76 & 82.85 & 32.58 & 6.9 & 3.27 & 56.27 & 12.65 \\
\hline & 4.22 & 29.55 & 81.1 & 31.28 & 5.25 & 3.08 & 49.75 & 12.5 \\
\hline & 4.15 & 29.35 & 80.95 & 29.75 & 5.08 & 3 & 49.05 & 12.45 \\
\hline & 4.37 & 29.23 & 80.55 & 28.15 & 4.57 & 2.88 & 47.68 & 12.35 \\
\hline & 4.88 & 28.52 & 78.47 & 27.63 & 4.35 & 2.8 & 43 & 12.22 \\
\hline Value & 3.67 & 4.1 & 9.75 & 12.1 & 2.85 & 1.95 & 22.48 & 0.63 \\
\hline Value at $1 \%$ & 1 & 1.12 & 2.66 & 3.30 & 0.78 & 0.53 & 6.13 & 0.17 \\
\hline response degree & & $13 \%$ & $11 \%$ & $31 \%$ & $40 \%$ & $41 \%$ & $34 \%$ & $5 \%$ \\
\hline realigning & & 5 & 6 & 4 & 2 & 1 & 3 & 7 \\
\hline
\end{tabular}

Data in Table (2) indicated that Giza 90 variety of trash content by $1 \%$ led to decrease, span length (SL $2.5 \%$ ) $1.86 \mathrm{~mm}$, uniformity ratio (Ur) $2.94 \%$, fiber strength in gram/tex 4.37 (g/tex), micronaire reading 0.68 reflectance degree $(\mathrm{Rd} \%) 7.51 \%$ and the yellowness degree $(+\mathrm{b})$ decreased 0.44 . On the other hand, increased the elongation $\% 0.24$. All characters are responded negatively to the increment of trash content except that of the yellowness degree $(+b)$ characters which, increased by increasing the trash percentage, the response degree could be arranged in descending order as follows: The highest values decreasing and the first arrangement is by micronaire reading by $34 \%$, strength (g/tex) by $28 \%$, reflectance by $23 \%$, span length (SL
$2.5 \%$ ) by $14 \%$, uniformity ratio (Ur) by $8 \%$ and the yellowness degree $(+\mathrm{b})$ by $8 \%$. In contrast, increasing the elongation by $7 \%$ showed that Alien et al. (2007). Span lengths at $2.5 \%$ (SL $2.5 \%$ ) mm, uniformity ratio (Ur) \%, fiber strength in gram/tex. (St..g/tex) fiber elongation\% (Elon.)\%, Micronaire reading (Mic.) reflectance $\%(\mathrm{Rd}) \%$, yellowness $(+\mathrm{b}) .(\mathrm{Y})=$ total trash content at $(\mathrm{MTM}) \quad$ Value $=($ Max-min $)$. Value at $1 \%$ $($ trash at $1 \%)=,(\operatorname{Max}-\operatorname{mine})$ at $(\mathrm{Y}) /(\mathrm{Max}-$ mine $)$ at characters.

Response degree $=($ Max $-\mathrm{min})$ at characters $/$ (height value) at characters. Realigning $=$ the highest values decreasing and the first arrangement. 
Table 2. Effect of trash content and response degree on fiber quality for Egyptian cotton Giza $\mathbf{9 0}$ variety.

\begin{tabular}{|c|c|c|c|c|c|c|c|c|}
\hline \multirow{2}{*}{ variety } & \multirow{2}{*}{$\begin{array}{c}\text { trash } \\
\text { content }\end{array}$} & \multicolumn{2}{|c|}{ ML } & \multirow{2}{*}{ St. g/tex } & \multirow{2}{*}{ Elon. } & \multirow{2}{*}{ Mic } & \multirow{2}{*}{$\mathbf{R d} \%$} & \multirow{2}{*}{ b+ } \\
\hline & & $2.50 \%$ & Ur\% & & & & & \\
\hline \multirow{9}{*}{ G 90} & 1.74 & 30.29 & 86.55 & 35.58 & 7.33 & 4.42 & 73.55 & 12.7 \\
\hline & 1.75 & 30.21 & 86.05 & 35.47 & 7.24 & 4.38 & 67.47 & 12.68 \\
\hline & 2.46 & 27.75 & 85.6 & 35.42 & 7.2 & 4.37 & 65.42 & 12.32 \\
\hline & 3.11 & 27.35 & 82.75 & 28.09 & 7.17 & 3.14 & 62.04 & 12.18 \\
\hline & 3.19 & 27.23 & 82.43 & 28.02 & 7.17 & 3.14 & 61.38 & 12.02 \\
\hline & 3.65 & 26.87 & 81.57 & 27.33 & 7.15 & 3.05 & 58.35 & 11.97 \\
\hline & 3.72 & 26.87 & 80.98 & 26.87 & 7.04 & 3.01 & 57.8 & 11.95 \\
\hline & 3.77 & 26.39 & 80.7 & 25.87 & 7.04 & 2.92 & 57.47 & 11.91 \\
\hline & 3.99 & 26.01 & 79.94 & 25.75 & 6.8 & 2.9 & 56.65 & 11.7 \\
\hline Value & 2.25 & 4.18 & 6.61 & 9.83 & 0.53 & 1.52 & 16.9 & 1 \\
\hline Value at $1 \%$ & 1 & 1.86 & 2.94 & 4.37 & 0.24 & 0.68 & 7.51 & 0.44 \\
\hline response degree & & $14 \%$ & $8 \%$ & $28 \%$ & $7 \%$ & $34 \%$ & $23 \%$ & $8 \%$ \\
\hline realigning & & 4 & 5 & 2 & 6 & 1 & 3 & 5 \\
\hline
\end{tabular}

Data in Table (3) indicated that Giza 86 variety of trash content by $1 \%$ led to decrease, span length (SL $2.5 \%) 2.03 \mathrm{~mm}$, uniformity ratio (Ur) $3.2 \%$, fiber strength in gram/tex 3.63 (g/tex), micronaire reading 0.67 and reflectance degree (Rd\%)5.98\%. Alternatively, increased the yellowness degree $(+\mathrm{b}) 1.2$ and elongation\% 0.43. All characters are responded negatively to the increment of trash content except that of the yellowness degree (+b) characters which, increased by increasing the trash percentage, the response degree could be arranged in descending. The highest values decreasing and the first arrangement is micronaire reading by $40 \%$, strength (g/tex) by $32 \%$ reflectance by $23 \%$, span length (SL $2.5 \%$ ) by $19 \%$ and uniformity ratio (Ur) by $11 \%$. Inside out, increasing elongation by $+17 \%$ and the yellowness degree $(+b)$ by $+31 \%$ found that Chanel et al. (2011).

Table 3. Effect of trash content and response degree on fiber quality for Egyptian cotton Giza 86 variety.

\begin{tabular}{|c|c|c|c|c|c|c|c|c|}
\hline \multirow{2}{*}{ variety } & \multirow{2}{*}{$\begin{array}{c}\text { trash } \\
\text { content }\end{array}$} & \multicolumn{2}{|c|}{ ML } & \multirow{2}{*}{ St. g/tex } & \multirow{2}{*}{ Elon. } & \multirow{2}{*}{ Mic } & \multirow{2}{*}{ Rd\% } & \multirow{2}{*}{ b+ } \\
\hline & & $2.50 \%$ & Ur\% & & & & & \\
\hline \multirow{8}{*}{ G 86} & 1.78 & 33.49 & 89.15 & 43.77 & 7.7 & 5.07 & 78.07 & 12.05 \\
\hline & 1.47 & 33.45 & 89.12 & 43.2 & 7.38 & 4.87 & 77.02 & 10.1 \\
\hline & 1.89 & 32.88 & 87.42 & 42.05 & 7.35 & 4.66 & 76.67 & 10.1 \\
\hline & 3.61 & 31.45 & 84.87 & 37.88 & 7.28 & 4.12 & 67.8 & 9.5 \\
\hline & 3.53 & 30.98 & 83.6 & 36.6 & 7.15 & 3.77 & 67.68 & 8.78 \\
\hline & 3.53 & 30.74 & 83.38 & 34.02 & 7 & 3.73 & 67.22 & 8.55 \\
\hline & 3.9 & 29.95 & 83.3 & 33 & 6.68 & 3.39 & 65.1 & 8.5 \\
\hline & 4.52 & 27.29 & 79.4 & 29.65 & 6.38 & 3.04 & 59.83 & 8.35 \\
\hline Value & 3.05 & 6.2 & 9.75 & 14.12 & 1.32 & 2.03 & 18.24 & 3.7 \\
\hline Value at $1 \%$ & 1 & 2.03 & 3.20 & 3.63 & 0.43 & 0.67 & 5.98 & 1.21 \\
\hline response degree & & $19 \%$ & $11 \%$ & $32 \%$ & $17 \%$ & $40 \%$ & $23 \%$ & $31 \%$ \\
\hline realigning & & 5 & 7 & 2 & 6 & 1 & 4 & 3 \\
\hline
\end{tabular}

Data in Table (4) indicate that Giza 45 variety of trash content by $1 \%$ led to decrease, span length (SL $2.5 \%) 0.88 \mathrm{~mm}$, uniformity ratio (Ur) $1.73 \%$, fiber strength in gram/tex 2.42 (g/tex), elongation\% 0.57 , micronaire reading -0.36 and reflectance degree $(\operatorname{Rd} \%) 0.27 \%$.subsequently, increased the yellowness degree $(+b)$ 0.27. All characters are responded negatively to the increment of trash content except that of the yellowness degree $(+b)$ characters which, increased by increasing the trash percentage, the response degree could be arranged in descending order as follows: The highest values reducing and the first arrangement are by micronaire reading by $26 \%$,elongation by $18 \%$,reflectance by $17 \%$,strength 
(g/tex) by $13 \%$ span length (SL 2.5\%) by 6\% and uniformity ratio (Ur) by 5\%.Topsy-turvy, the yellowness degree $(+\mathrm{b})$ by $6 \%$ found that Siddaiah $\boldsymbol{e t}$ al., (1999).

Table 4. Effect of trash content and response degree on fiber quality for Egyptian cotton Giza 45 variety.

\begin{tabular}{|c|c|c|c|c|c|c|c|c|}
\hline \multirow{2}{*}{ variety } & \multirow{2}{*}{$\begin{array}{c}\text { trash } \\
\text { content }\end{array}$} & \multicolumn{2}{|c|}{ ML } & \multirow{2}{*}{ St. g/tex } & \multirow{2}{*}{ Elon. } & \multirow{2}{*}{ Mic } & \multirow{2}{*}{$\mathbf{R d \%}$} & \multirow{2}{*}{ b+ } \\
\hline & & $2.50 \%$ & Ur\% & & & & & \\
\hline \multirow{5}{*}{ G 45} & 1.34 & 36.54 & 89.48 & 44.88 & 7.48 & 3.42 & 75.04 & 10.78 \\
\hline & 2.42 & 35.88 & 88.45 & 42.92 & 7.47 & 3.15 & 70.92 & 10.33 \\
\hline & 3.57 & 35.2 & 86.35 & 41.48 & 6.5 & 2.78 & 64.03 & 10.3 \\
\hline & 3.61 & 34.85 & 86.02 & 40.77 & 6.47 & 2.72 & 63.77 & 10.14 \\
\hline & 3.78 & 34.38 & 85.27 & 38.97 & 6.1 & 2.53 & 62.48 & 10.12 \\
\hline Value & 2.44 & 2.16 & 4.21 & 5.91 & 1.38 & 0.89 & 12.56 & 0.66 \\
\hline Value at $1 \%$ & 1 & 0.88 & 1.73 & 2.42 & 0.57 & 0.36 & 5.15 & 0.27 \\
\hline response degree & & $6 \%$ & $5 \%$ & $13 \%$ & $18 \%$ & $26 \%$ & $17 \%$ & $6 \%$ \\
\hline realigning & & 5 & 6 & 4 & 2 & 1 & 3 & 5 \\
\hline
\end{tabular}

Data in Table (5) indicate that Giza 70 variety of trash content by $1 \%$ led to decrease, Spain length (SL $2.5 \%$ ) $1.5 \mathrm{~mm}$, uniformity ratio (Ur) $2.44 \%$, Fiber strength in gram/tex 2.63 (g/tex), elongation $\% 0.61$, micronaire reading 0.61 and reflectance degree $(\mathrm{Rd} \%) 5.07 \%$. Formerly, augmented the yellowness degree (+b) 0.71. All characters are responded negatively to the increment of trash content except that of the yellowness degree $(+b)$ characters which, increased by increasing the trash percentage, the response degree could be arranged in descending order as follows. The highest values reducing and the first arrangement are by micronaire reading by $34 \%$, elongation by $18 \%$, reflectance by $15 \%$, strength (g/tex) by $13 \%$ spain length (SL $2.5 \%$ ) by $9 \%$ and uniformity ratio (Ur) by $6 \%$ Collective then, yellowness degree $(+\mathrm{b})$ by $15 \%$ mentioned that Nickerson et al., (1959).

Table 5. Effect of trash content and Response degree on fiber quality for Egyptian cotton Giza $\mathbf{7 0}$ variety.

\begin{tabular}{|c|c|c|c|c|c|c|c|c|}
\hline \multirow[b]{2}{*}{ variety } & \multirow{2}{*}{$\begin{array}{c}\text { tras } \\
\text { h } \\
\text { cont } \\
\text { ent }\end{array}$} & \multicolumn{2}{|c|}{ ML } & \multirow[b]{2}{*}{ St. g/tex } & \multirow[b]{2}{*}{ Elon. } & \multirow[b]{2}{*}{ Mic } & \multirow[b]{2}{*}{ Rd\% } & \multirow[b]{2}{*}{ b+ } \\
\hline & & $2.50 \%$ & Ur\% & & & & & \\
\hline \multirow{7}{*}{ G 70} & 1.45 & 35.63 & 89.02 & 44.07 & 7.45 & 3.94 & 73.67 & 10.23 \\
\hline & 2.55 & 35.27 & 88.98 & 43.2 & 7.38 & 3.73 & 69.92 & 10.15 \\
\hline & 2.20 & 34.03 & 86.48 & 42.95 & 6.68 & 3.18 & 69.38 & 10.12 \\
\hline & 2.28 & 33.2 & 86.27 & 40.98 & 6.67 & 3.17 & 66.67 & 10.07 \\
\hline & 3.15 & 32.97 & 85.27 & 40.35 & 6.47 & 2.98 & 66.25 & 9.92 \\
\hline & 3.66 & 32.95 & 84.73 & 39.95 & 6.28 & 2.78 & 62.92 & 9.48 \\
\hline & 3.6 & 32.32 & 83.62 & 38.25 & 6.1 & 2.6 & 62.47 & 8.67 \\
\hline Value & 2.21 & 3.31 & 5.4 & 5.82 & 1.35 & 1.34 & 11.2 & 1.56 \\
\hline Value at $1 \%$ & 1 & 1.50 & 2.44 & 2.63 & 0.61 & 0.61 & 5.07 & 0.71 \\
\hline Response degree & & $9 \%$ & $6 \%$ & $13 \%$ & $18 \%$ & $34 \%$ & $15 \%$ & $15 \%$ \\
\hline realigning & & 5 & 6 & 4 & 2 & 1 & 3 & 3 \\
\hline
\end{tabular}

Data in Table (6) indicate that Giza 88 variety and of trash content by $1 \%$ led to decrease, span length (SL $2.5 \%$ ) $1.64 \mathrm{~mm}$, uniformity ratio (Ur) $2.54 \%$, fiber strength in gram/tex 2.08 (g/tex), elongation\% 0.69 , micronaire reading 0.79 and reflectance degree $(\operatorname{Rd} \%) 6.69 \%$. Improved, the yellowness degree $(+\mathrm{b})$ 0.63. All characters are responded negatively to the increment of trash content except that of the yellowness degree $(+b)$ characters which, increased by increasing the trash percentage, the response degree could be arranged in descending order as follows: The highest values reducing and the first arrangement are by micronaire reading by $42 \%$, elongation by $33 \%$,strength (g/tex) by $23 \%$,span length (SL 2.5\%) by $19 \%$, reflectance by $17 \%$ and uniformity ratio (Ur) by $11 \%$.Cooperativethe yellowness degree $(+b)$ by $15 \%$. 
Table 6. Effect of trash content and response degree on fiber quality for Egyptian cotton Giza $\mathbf{8 8}$ variety.

\begin{tabular}{|c|c|c|c|c|c|c|c|c|}
\hline \multirow{2}{*}{ variety } & \multirow{2}{*}{$\begin{array}{c}\text { trash } \\
\text { content }\end{array}$} & \multicolumn{2}{|c|}{ ML } & \multirow{2}{*}{ St. g/tex } & \multirow{2}{*}{ Elon. } & \multirow{2}{*}{ Mic } & \multirow{2}{*}{ Rd\% } & \multirow{2}{*}{ b+ } \\
\hline & & $2.50 \%$ & $\mathrm{Ur} \%$ & & & & & \\
\hline \multirow{9}{*}{ G 88} & 0.82 & 34.9 & 88.07 & 42.9 & 8 & 4.32 & 66.53 & 13.58 \\
\hline & 0.79 & 34.83 & 86.45 & 41.05 & 7.62 & 4.13 & 66.45 & 13.4 \\
\hline & 1.25 & 33.72 & 86.3 & 40.13 & 7.45 & 3.33 & 64.77 & 13.17 \\
\hline & 1.54 & 33.15 & 85.12 & 39.18 & 6.58 & 2.78 & 63.12 & 13.17 \\
\hline & 1.69 & 32.42 & 83.92 & 37.6 & 6.18 & 2.58 & 61.95 & 12.98 \\
\hline & 1.755 & 32.33 & 83.6 & 37.37 & 6.17 & 2.57 & 61.67 & 12.95 \\
\hline & 1.85 & 31.52 & 81.5 & 33.53 & 5.53 & 2.33 & 61.02 & 12.95 \\
\hline & 2.15 & 31.47 & 80.85 & 32.25 & 5.22 & 2.32 & 58.63 & 12.48 \\
\hline & 2.60 & 29.47 & 78.85 & 28.68 & 5.08 & 2.27 & 54.75 & 12.47 \\
\hline Value & 1.78 & 5.43 & 9.22 & 14.22 & 2.92 & 2.05 & 11.78 & 1.11 \\
\hline Value at $1 \%$ & 1 & 5.64 & 5.24 & 7.99 & 1.64 & 1.16 & 6.69 & 0.63 \\
\hline response degree & & $29 \%$ & $11 \%$ & $33 \%$ & $37 \%$ & $48 \%$ & $18 \%$ & $8 \%$ \\
\hline realigning & & 4 & 6 & 3 & 2 & 1 & 5 & 7 \\
\hline
\end{tabular}

Correlation coefficients between trash percentages (Y) and fiber properties:

Correlation coefficients were computed within each variety (by trash percentages within each of variety under study three extra-long staple varieties, (Giza 45, Giza 70 and Giza 88), one delta long- staple varieties, (Giza 86), and two Upper Egypt long- staple varieties,(Giza 80, and Giza 90). To study the effect of the trash content on: span length at $2.5 \%$, (ML 2.5\%) $\mathrm{mm}$, uniformity ratio (Ur \%), fiber strength in gram/tex. St. (g/tex) fiber elongation\% (Elon.\%), micronaire reading (Mic.) reflectance degree ( $\mathrm{Rd} \%)$ and yellowness $(+b)$.

The data shown in Table (7) clearly indicate that there was a downward trend as for the ML 2.5\%, Ur\%, St. (g/tex), Elon\%, Mic, Rd, with trash percentages (Y) in Giza 80, this very high significantly decreasing of negatively in the relationship between fiber properties (at this) but non-significant decreasing of negatively correlation coefficients in yellowness $(+b)$.

On the contrary the correlation coefficients in Giza 90, have negative signs, very high between trash percentages and ML 2.5\%, Ur\%, St. (g/tex), Mic, Rd, but Elon $\%$ and $+\mathrm{b}$ non-significant.

The characters was high significantly decreased, as affected by trash contends, at Giza 86, but nonsignificant positive in the Elon $\%$ and $+b$ in this varity.

On the contrary the all characters are responded very high significant decreasing in Giza $\mathbf{4 5}$ as affected by trash contends, but the ( st. + b) under the study was non significantly. These results were in agreement with ElTabbakh et al., (1985) and El-Sayed (2000).

Hence, correlation coefficients between trash percentages $(\mathrm{Y})$ in the all characters was non significantly decreased, but the Reflectance degree ( $\mathrm{Rd}$ $\%)$ a negative very high significant effect, in Giza 70.

On the other hand the all characters are responded very high significant decreasing to the increment of trash content except that the all characters negatively but yellowness (+b) positively in the Giza $\mathbf{8 8}$ These results are in agreement with McAlister and Rogers (2005), Siddaiah et al. (2004), Allen et al., (2007) and Chanel et al., (2011).

Table 7. Coefficients of simple correlation between trash content and each of fiber properties for some Egyptian cotton varieties.

\begin{tabular}{|c|c|c|c|c|c|c|c|c|c|}
\hline category & Varity & $\begin{array}{c}\text { trash } \\
\text { content }\end{array}$ & ML2.50\% & $\mathrm{Ur} \%$ & St.g/tex & Elon. & Mic & Rd\% & b+ \\
\hline Delta Egypt long- staple & Giza86 & 3.05 & $-0.89 * *$ & $-0.96 * *$ & $-0.96 * *$ & $+0.75^{*}$ & $-0.89 * *$ & $-0.99 * *$ & +0.83 \\
\hline \multirow{2}{*}{ Upper Egypt long- staple } & Giza80 & 3.67 & - $0.97 * *$ & $-0.99 * *$ & $-0.97 * *$ & $-0.85 * *$ & $-0.89 * *$ & $-0.98 * *$ & -0.10 \\
\hline & Giza90 & 2.25 & $-0.93 * *$ & $-0.95 * *$ & $-0.95^{* *}$ & -0.32 & $-0.94 * *$ & $-0.96 * *$ & +0.32 \\
\hline \multirow{3}{*}{ extra- long staple } & Giza45 & 2.44 & $-0.96 * *$ & $-0.98 * *$ & -0.71 & $-0.92 *$ & $-0.98 * *$ & $-0.99 * *$ & +0.35 \\
\hline & Giza70 & 2.21 & -0.48 & -0.66 & -0.03 & -0.49 & $-0.78 *$ & $-0.95^{* *}$ & +0.39 \\
\hline & Giza88 & 1.76 & $-0.88 * *$ & $-0.95 * *$ & $-0.88 * *$ & $-0.91 * *$ & $-0.92 * *$ & $-0.98 * *$ & $+0.94 * *$ \\
\hline
\end{tabular}


Upper half means (U.H.M) mm Uniformity index (UI) fiber strength in gram/tex.St. (g/tex) Fiber elongation \% (Elon.) Micronaire reading (Mic) reflectance (Rd \%) yellowness (+b). Non-significant ( ), significant at $0.05(*)$ and high significant at $0.01(* *)$ probability.

\section{Acknowledgement}

First of all, Ultimate thanks are due to Allah, who without his aid this work could not be done. It is great honor to have this work, by Prof Dr. Mohamed Khaled Abd-Elftah Cotton Research Institute, for his valuable help.

\section{References}

A.S.T.M. (1977). Designation D1447 In Annual Book of ASTM Standards. ASTM International, PA., USA.

A.S.T.M. (1993). Standard test method for measurement of cotton fibers by high volume instruments (HVI) Spin-lab System of ZeIlweger Uster, Inc.) (D: 4605-88).P.409-507. In Annual Book of ASTM standards.7- 02, textiles. ASTM. West Conshohocken, PA high volume instrument color and trash of cotton.

A.S.T.M. (2012a). Standard test method for non-lint content of cotton (D:2812). In Annual Book of ASTM Standards. ASTM International, West Conshohocken, PA.,USA.

A.S.T.M. (1998). On materials. D: 1578 - 67, D: 142560, D: 1440-65, D:1445-67, D:1448-68, D: 2812-95. In Annual Book of ASTM Standard. ASTM. Philadelphia, PA.,USA.

Ahmed M.S., Garawin M.S.S., Ahmed N.T. and Sheref M.V. (1987). The reliability of using instrumental measurements of trash content, micronaire reading and color in the evaluation of cotton grade. Egypt. Cotton Gaz. 88: 40-53.

Alien A., Foulk J. and Gamble G. (2007). Fourier Transform Infrared Spectroscopy Analysis of Cotton Trash. J. of Cotton Sci., Vol. 11, pp.68-74.ISSN 15236919.

Anthony W. S. (1994). The effect of gin machinery on measurement of high volume instrument color and trash of cotton. Transactions of the ASAE. 37(2): 373-380.

Armijo C.B., Baker K.D., Hughs S.E., Barnes E.M. and Gillum M.N. (2009). Harvesting and seed cotton cleaning of a cotton cultivar with a fragile seed coat. J. of Cotton Sci., 13: 158-165.

Baker R., Brashears A. and Lalor W. (1992). Influence of lint cleaning on fine trash levels. Trans. ASAE., 35 (5): 1355-1359.
Chanel F., James R. and John F. (2011). Investigation of the impact of instrumental and software applications on cotton and botanical trash identification by Ultraviolet-Visible and NearInfrared Spectroscopy. J. of cotton sci., 15: 170-178.

Dunn T.A., Misra S.K., Barker G.L. and Baker R.V. (2002). Predicting lint cleaner efficiency and fiber quality characteristics and cotton ginning. App. Eng. In Agric., American Soc. Agric. Eng., 18 (2): 141146.

Foulk, J; David, M. A. and Kulasekera, B. K. (2006). Detecting the cotton trash particle size distribution in Mill Lay down using HVI trash meter software., $J$. of Tex. And APP., Tech and Management., 5 (2):111.

Galyon; M.S. and F. M Shofner (1992): Through the mill study of neps, trash and short, fiber content proceeding of the Beltwide cotton. textile processing conference, 1253- 1263

Marey, S.A.; Kable, A.E. and Sayed-Ahmed, I.F. (2012). Performance evaluation of two different seed cotton trash extractors. American - Eurasian J. Agric. and Environ. Sci., 12 (10): 1356-1363.

Mc Alister, D.D. and Rogers, D.C. (2005). The effect of harvesting procedures on fiber and yarn quality of ultra-narrow-row cotton. J. cotton Sci., 9 (1) : 15-23.

Misra, N.S.; Bennett, B. and Baker, G. (1999). Gin lint cleaning to maximize producer net returns revisited. Applied Engineering in Agric., 15 (6): 621 626.

Nickerson O., Temaszweek J. J. and Elba F. F. (1959). Cotton grade studied; Trash and colour. The Empire Cotton G.R., 39(4): 304.

Richman, K.R. and Fachini, J.I. (1993). New bur extractor. Beltwide cotton conf. proceedings, new Developments from industry. National cotton council, Memphis., TN., 55.

Snedecor G.W., Cochran W.G.(1989). Statistical Methods. 8 th Edition, Iowa State Univ., Press, Ames, Iowa. USA.

Siddaiah M., Lieberman M.A., Hughs S.E., Foulk J. and Clemson S. (2004). Small trash identification in cotton using imaging techniques. Beltwide Cotton conf. San Antonio, January 5-9., 2394-2396.

Siddaiah M.A., Lieberman M.A., Hughs E.S. and Prasad R.N. (1999). A soft computing approach to classification of trash in ginned cotton. Proceeding of the Eighth international FU22 systems Association world congress., I: 151-155.

Xu, B. and Fang, C. (1999). Clustering analysis for cotton trash classification. Textile Res. J., 69 (9): 656-662. 


\title{
تأثثر نسبة الشوائب على قياسات صفات جودة التيلة فى القطن المصري
}

\author{
حامد سيد أحمد أحمد \\ مركز البحوث الزراعية - معهل بحوث القطن - الجيزه - مصر احثر
}

أجريت هذه الدراسة بمعامل تكنولوجيا القطن التابعة لمعهد بحوث القطن مركز البحوث الزراعية بالجيزة على عينات محصول 2012 - 2013 بهدف

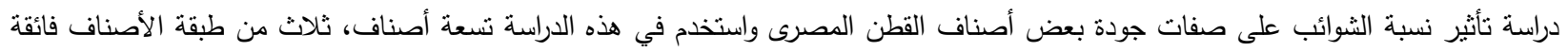

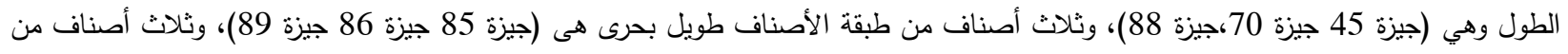

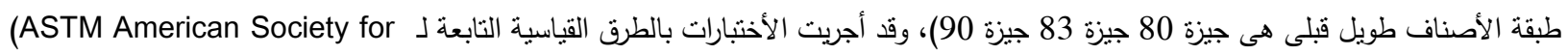
Testing and Material)

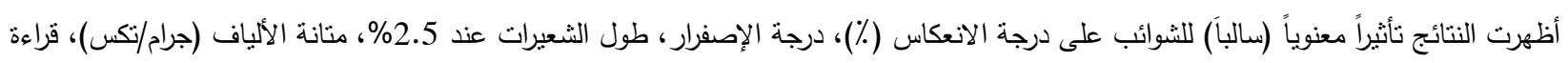

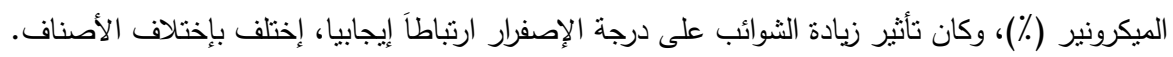

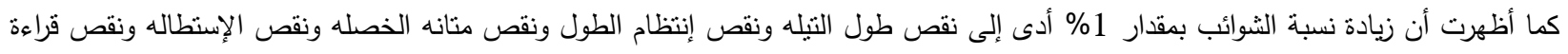

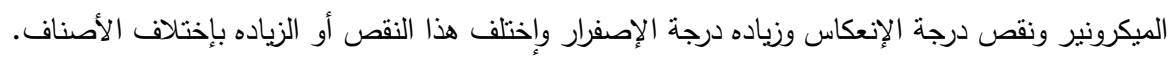

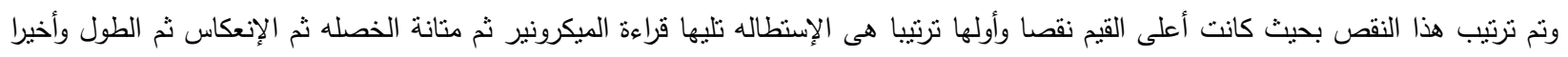
الإنتظاميه، إختلف هذا الترتيب بإختلاف الأصناف من حيث درجة تأثير الثنوائب فى مقدار وقيمة الصفه. 